\title{
SPACES OF PREPARATION: THE 'ACTON HILTON' AND CHANGING PATTERNS OF TELEVISION DRAMA REHEARSAL
}

(6,770 words including notes $\&$ references)

\section{Dr Richard Hewett}

Correspondence:

Richard Hewett, Flat 4, 158 Muswell Hill Road, London N10 3JE, UK,

Email: richard.hewett@rhul.ac.uk

\section{Biography}

Richard Hewett teaches television and film at Royal Holloway, the University of London. His $\mathrm{PhD}$ thesis, Acting for Auntie: From Studio Realism to Location Realism in BBC Television Drama, 1953-2008, was completed in 2012 at the University of Nottingham. Publications include the article 'Acting in the New World: Studio and Location Realism in Survivors' for the Journal of British Cinema and Television Volume 10.2, and 'Who is Matt Smith?: Performing the Doctor' in O'Day, Andrew (ed.), The Eleventh Hour: A Critical Celebration of the Matt Smith and Steven Moffat Era (I.B. Tauris, 2013). 


\title{
Spaces of preparation: The 'Acton Hilton' and changing patterns of television drama rehearsal
}

\begin{abstract}
It is only comparatively recently that performance in arenas other than theatre and cinema has begun to receive serious academic attention. The 'Spaces of Television' project and the University of York's 'Playing the Small Screen' symposium have each opened up discussions regarding the impact of production process and space upon television acting, yet little consideration has been given to those spaces in which performances were traditionally prepared prior to studio transmission or recording. This article attempts to address this by focusing on the BBC's 'Television Rehearsal Rooms', better known by those who used them as the 'Acton Hilton', which offers a precise model of the 'outside' rehearsal process which characterised multi-camera studio production. A creative hub for not only drama, but also sitcom and light entertainment, the Hilton represented an extended community for the many performers who gathered there to rehearse, a community that has all but disappeared in the modern era of single camera location work, where prior rehearsal of the type conducted at Acton has virtually disappeared. Drawing upon a combination of archive research and interviews with practitioners, this piece examines the important role played by the Acton Hilton in the history of UK television acting.
\end{abstract}

\section{Keywords:}

BBC; acting; rehearsal; performance; multi-camera; Television Centre; 1970s; 1980s; 1990s 


\section{SPACES OF PREPARATION: THE 'ACTON HILTON' AND CHANGING PATTERNS OF TELEVISION DRAMA REHEARSAL}

While television studies has paid a great deal of attention to the importance of individual figures and institutions in the development of the medium's history, the significance of those buildings where much of their work was carried out is less frequently highlighted. The closure last year of BBC Television Centre at London's Wood Lane saw media commentators and former personnel alike competing to pay tribute to the 'dream factory" not an appellation by which any who worked there had previously known it - with an entire evening devoted to the site on BBC Four; an indication of the importance such structures can take on in the national consciousness.

While few would take issue with Television Centre's significance in British broadcasting, its closure put me in mind of another BBC building, whose decommissioning and (unlike the listed Wood Lane property) demolition a few years ago went almost entirely un-trumpeted by the media, and indeed the BBC itself. The Corporation's North Acton Television Rehearsal Rooms, a seven-storey block known ironically by those who used it as the 'Acton Hilton', first came into use in 1970 as a creative hub for not just drama but also comedy and light entertainment productions. For every half-hour of content recorded at Television Centre, around a week's prior preparation had taken place at Acton, yet the Rehearsal Rooms' role in television history has thus far been largely neglected. Former Head of Studio Management Mike Jones's website ${ }^{2}$ aside, scant attention has been paid to a building which, perhaps even more than Television Centre, represented the processes of a mode of programme-making that has all but disappeared in the modern era of decentralisation and location filming. Drawing upon a combination of research conducted at the BBC's Written Archive Centre and original interviews with several of those who worked at Acton, 
this article represents an attempt to redress that lack. Following a brief history of the rooms, I shall discuss their significance as a space of preparation and, perhaps most importantly, a community for the many actors and directors who worked there between the 1970s and the early 1990s, before examining how patterns of preparation have changed between then and now.

Given the predominantly live nature of British television drama from 1936 until the early 1960s, it might be thought that the necessity for rehearsal would, from the outset, have required the provision of some kind of space specifically designed for this purpose, and indeed at the spacious Alexandra Palace at least one area was provided in addition to Studios $\mathrm{A}$ and $\mathrm{B}{ }^{3}$ However, the bulk of rehearsal was conducted at what were termed 'outside' rehearsal rooms; these were existing premises, many of which were initially located in the West End for the convenience of actors working primarily in theatre, which were leased on a renewable short-term basis by the BBC. Thirteen such locations were in use in $1950,{ }^{4}$ and by 1959 the number had more than doubled to 27 halls, missions and boys clubs. ${ }^{5}$ In the interim, much of the BBC's television production had moved from Alexandra Palace to the refurbished Gaumont film studios at Lime Grove, Television Centre still being in the early stages of construction. The original plan put forward in 1953 was for the 'tail' of the Television Centre 'question mark' to include a rehearsal block, with provision made for 17 rooms occupying around 25,000 square feet. ${ }^{6}$ However, over the next year a number of questions and objections were raised regarding the height, grouping and soundproofing of the rooms. In January 1954 a Working Party reported that, at $£ 11,200$ per annum, the cost of continuing to rent outside rooms was marginally cheaper than the $£ 11,700$ that would be required to maintain the proposed rehearsal spaces at Television Centre, but suggested as a third option "the renting of a special building."7 This possibility was not pursued by Administrative Officer A.M. Andrews, who concluded that 'if space permits we should 
recommend that rehearsal rooms be built at the Television Centre. ${ }^{8}$ Just five months later, however, Controller of Programmes Cecil McGivern announced that, as the number of rehearsal rooms deemed necessary had now risen to 26 , 'it would be most unwise to put these ... on the Television Centre site when it seems that the positioning of the rehearsal rooms would confine the number of studios to a maximum of twelve. ${ }^{9}$ The possibility of finding a site near Television Centre was again raised, but following a subsequent costing of approximately $£ 500,000$ the project was shelved indefinitely, with no provision made for it in the BBC's five-year budget. ${ }^{10}$

During Television Centre's construction the canteen was in fact employed for rehearsal, but this practice ceased when Stage III of building work commenced in the late 1950s. ${ }^{11}$ It was then suggested that those studios which would be vacated once Lime Grove productions moved to Wood Lane could be converted into rehearsal space. ${ }^{12}$ In the event, outside rooms continued to be rented; by 1963, the number used had risen to $31 .^{13}$ These rehearsal spaces were not, however, always conducive to the task at hand. The BBC's archives contain two files of correspondence with the actors' union Equity between 1952 and 1966, largely comprising of complaints regarding cleanliness, the absence of designated changing rooms and telephone facilities, and, above all, heating. This seems to have been a major factor in the outside rooms used in the early 1950s, director Alvin Rakoff recalling that: 'You'd get one little gas burner which always ran out; everyone was bundled up. ${ }^{14}$ In the early 1960s, however, a process of refurbishment was undertaken, and more suitable replacements were sought for existing rooms. ${ }^{15}$ By 1965 twelve drill halls at least had been fitted with gas central heating, ${ }^{16}$ and all the properties leased were inspected on a six-monthly basis. ${ }^{17}$ Graded with regard to popularity, amenities, access, parking and dressing room space, rooms were placed into three categories. 'A' was for 'large and first class rooms, suitable for all productions'; 'B' was allocated to rooms which were 'adequate... but with 
some limitations,' while 'C' designated 'rooms which should be replaced as soon as better rooms become available. ${ }^{18}$ While the $\mathrm{BBC}$ was seemingly quick to rectify deficiencies, Dame Edith Evans writing in 1961 to congratulate the Corporation on the speed with which they responded to her complaint regarding the lack of hangers for coats and hats, ${ }^{19}$ this did not prevent Hugh Jenkins, Assistant General Secretary of Equity, embarking on a letterwriting campaign in The Times in late 1962 and early 1963, denouncing the provision made for rehearsal by the BBC. Inspired by a complaint from Maigret (BBC, 1960-63) star Rupert Davies, Jenkins pilloried the Corporation intermittently over the next 18 months for the 'derelict buildings ${ }^{20}$ in which they forced their performers to prepare, comparing them unfavourably with their ITV rivals and lobbying for the provision of rooms at Television Centre. Despite the negative publicity generated by Jenkins' campaign, the BBC remained resolute, a 1963 report concluding that 'the present policy of leasing or hiring outside rehearsal rooms should be continued for the foreseeable future. ${ }^{21}$ It was conceded, however, that 'when funds can be made available a block of say ten rooms for BBC1 and 2 should be built for series programmes on a suitably accessible site. Alternatively a developer might build to the BBC's requirements and lease the premises at a market rent. ${ }^{22}$

After nearly fifteen years of indecision with regard to providing a permanent rehearsal block, the BBC's policy of leasing outside rehearsal rooms was thrown into sudden reverse when, in 1966, Harold Wilson's government opted to downsize the Territorial Army, announcing the sale of two thirds of the drill halls that currently provided the bulk of the BBC's rehearsal space. ${ }^{23}$ The procrastinations of the past apparently forgotten, on $21^{\text {st }}$ March 1967 the BBC officially sought permission for the construction of 18 'Television Rehearsal Rooms' (TRR), ${ }^{24}$ to be built on Victoria Road, just opposite North Acton Underground station, on the former site of Strachan Coach Works. ${ }^{25}$ Construction was undertaken by development company Allnatt London Properties Ltd; the BBC took a 99-year lease with the 
six-month option to purchase the freehold between $25^{\text {th }}$ December 1989 and $24^{\text {th }}$ June $1990 .{ }^{26}$ Preliminary work began in the autumn of $1968,{ }^{27}$ with the BBC formally taking possession of the premises on $1^{\text {st }}$ April $1970 .^{28}$ The significance of the BBC's investment in the new building block, in spite of its cost, is emphasised by Mike Jones:

In $1970 \mathrm{BBC}$ costs for the Television Rehearsal Rooms' lease alone was $£ 82,700$ per annum, and there were rates and running costs on top of this, whereas the highest price of an external room was $£ 3500$ per annum, with almost no extras to pay. It is important to appreciate that TRR was more than twice as expensive as eighteen external rooms, but the Television Service wanted to offer much better facilities to artists and also wanted security at a time that it seemed demand was steady and supply was diminishing. ${ }^{29}$

When completed, the block occupied a total of 60,239 square feet, with external parking spaces provided for 142 cars. The ground floor was 8,300 square feet, and consisted of a reception area and property store, in addition to a foreman's office, boiler house, toilets, etc.; two passenger lifts and two goods lifts were provided, plus stairs. Six floors of rehearsal rooms were built, each taking up 14,115 square feet; on each of these floors there were three rehearsal rooms of varying sizes (from 3,780 to 4,270 square feet; approximately 70 by 50 and 80 by 50 feet), plus a green room (decorated in green, gold and brown, 566 square feet, or 25 by 20 feet) and three small production offices (300 square feet). The finish of these rooms was industrial concrete and white brick, and durable lino tiles were used for flooring on each floor bar the first, which was sprung wood, designed for dance work. As with outside rooms, during rehearsal sets would be designated by the use of coloured tape on the floors, though the Acton rooms also provided notional 'mark-up' points along the perimeter. Central heating was provided via radiators, but there was no air conditioning. Lavatories on each 
floor were one sex only, which allegedly led to special negotiations over bookings dependent on whether the star was male or female. ${ }^{30}$ The top (seventh) floor featured a kitchen and canteen, which took up 3,502 square feet.

Acton's Television Rehearsal Rooms were officially opened on $4^{\text {th }}$ May 1970 , Head of Studio Management Basil Adams hailing it as 'probably the only purpose-built rehearsal centre in the world. ${ }^{31}$ Situated just two tube stops from Television Centre's Wood Lane, the building soon came to represent a reassuringly convenient and stable environment, fostering a wide communal spirit for the various performers who congregated there. Actress Elisabeth Sladen, a frequent visitor in the 1970s, summarised the atmosphere in her autobiography:

Everyone was there. Just walking through the doors that first time I saw Cilla Black, the Two Ronnies and the cast of The Onedin Line. By the time we got upstairs my mouth was agape. You soon got used to all the stars of the day coming and going, but I can't deny I wasn't thrilled [sic] to spot Sean Connery there one time and I'll never forget, for some reason, Prunella Scales ... struggling to buy chocolate from the vending machine. A brilliantly chatty concierge welcomed you in at the door and good old Ruby was in charge of the till and the food in the canteen on the top floor. The rehearsal rooms were massive - plenty of space to work through any show and mark it all out on the floor. Each room ... was square with two walls that were full of windows so the light absolutely poured in. It was a brilliant set-up because you could pop along the corridors or upstairs to peer through and watch other shows when you were on a break. ${ }^{32}$ 
Recalling his first visit to the Hilton in the early 1980s, Stephen Fry humorously mirrors Sladen's comments:

This soulless, sick-building-syndrome structure with its dripping, flaking and crumbling exterior, flickering fluorescent strip-lighting and smelly lifts was to be my second home ... I loved it. I loved the canteen, where you could nod hello to Nicholas Lyndhurst and David Jason, the kids from Grange Hill or the dancers from Top of the Pops. I loved the poles on plinths in the rehearsal rooms that could be moved around to stand in for doorways or entrances. I loved the tape on the floor that marked out rooms and camera positions in different colours, like sports-hall courts. I loved looking out across the dreary roofs of west London and knowing that I was here, working for the $\mathrm{BBC}$ with All Creatures Great and Small next door and Doctor Who the floor above. ${ }^{33}$

Others were less enthused, actor Matthew Waterhouse recalling of a 1980 visit: 'The lobby was grubbily carpeted. A man in a glass-windowed booth on the right half-looked, moodily, at IDs. ${ }^{34}$ In his memoir of working on Poldark (BBC, 1975-77), star Robin Ellis described the Hilton's atmosphere as 'hardly conducive to creative work. All the rooms are identical, their ceilings are low and there is no air. It's rather like working in a high rise block of flats. $^{35}$

Aesthetics aside, the Acton Hilton seems to have been of significance to actors less for its physical characteristics than the extended community it came to represent. Speaking in 2011, Roger Lloyd Pack echoed Sladen and Fry's affectionate view of the rehearsal block as a shared, communal space, in which actors from all walks of television could socialise 
together: 'The Acton Hilton [was] like a club, and I think actors like[d] meeting there, and it was a sociable thing that you felt part of the production. ${ }^{36}$

This 'sociable' aspect to relationships built up during rehearsal would extend beyond the rooms themselves. Local pub the Castle provided both a lunchtime alternative to the Acton canteen, and an opportunity for post-rehearsal socialising, as actor Kevin McNally recalls: 'There were actors you knew who you'd never been out with; you'd just been for a pint ... on the corner, next to the rehearsal room. You'd have whole relationships with people that you only met there. ${ }^{37}$ This venue provided a watering hole for any and all performers working at the Hilton, rather than being limited to the cast of a single production, as had been the case with outside rehearsal rooms. Whereas a sense of ensemble might previously have existed for teams working in isolation on separate dramas, there was now the opportunity for cross-fertilisation between different 'companies'. Actors and directors from different productions would be able to mingle freely, either in the canteen or at the Castle, leading to potential casting opportunities. In his autobiography, actor Matthew Waterhouse claims that even the car park at Acton provided a venue at which 'unemployed actors hung out in the afternoon, hoping to catch a director they'd worked with before on his way home. ${ }^{38}$ Kevin McNally describes the community spirit that could come to exist between directors and their favoured performers:

There were a whole bunch of them, and you'd work with them a lot, because there was a lot of television work and they had their ensemble of actors that they would always use, like a repertory company, and there was a sense of: 'There's no point in doing this unless we enjoy it.' Not that one was dilettante about the work at all, but there was certainly a sense of 'a life in the theatre', you know, that was transformed into television. ${ }^{39}$ 
McNally's choice of words here is particularly interesting in light of the fact that repertory theatre was already in decline by the time he became a professional actor in the 1970s. In the early days of television, 'rep' companies had been the field in which most actors would have received their professional grounding - along perhaps with touring groups - before taking the career step up into the West End. However, by the time the Hilton was conceived, the repertory system was in major decline; even by 1962 , there were only fifty to sixty active companies left in the country, ${ }^{40}$ meaning that the original 'rep' system was not one that younger actors like McNally would necessarily have experienced. The Acton Hilton, therefore, might have been regarded as a form of substitute for the diminishing theatre world by more established actors and directors, who then engendered a continued sense of the stage ensemble in younger generations working more frequently in television.

Before comparing the nature of theatre and television work, it is necessary to examine the rehearsal process that took place at Acton, which differed little from that established in the BBC's outside rehearsal rooms during the days of live drama. The first day would be given over to a full cast read-through of the script for the episode or play to be worked on, during which any cuts or amendments would be agreed. In addition to the director, this was the only day on which the script editor, producer and perhaps the writer would also be in attendance, along with representatives from the make-up and costume departments. After this first day, the director would be left to work with the cast on the learning of lines and blocking of movements around areas which, as already mentioned, were marked out with tape to represent the sets to be used in the studio on the day of recording. According to Shaun Sutton (Head of Drama 1967-81), this procedure was not dissimilar to that employed for theatre work: 
The process of rehearsing actors on television is basically no different ... it is the same building of lines into scenes, scenes into sequences, sequences into plays. Most actors like to know their 'moves', their theatrical business, before they put down their scripts .... they must be made secure in the mechanics of the production. This leaves them free to get on with their performances, which, after all, is what they are there for ... The wise TV director, having plotted a scene mechanically, will then run it again and again until everyone in it is not only comfortable, but understands precisely what the scene is about. $^{41}$

Towards the end of the rehearsal period, the entire episode would be performed in two separate rehearsal room 'runs'. The 'producer's run' would, as its name suggests, provide the programme producer with an initial idea of what the episode was going to look like, and offered a final opportunity, before the move into the studio, to amend, augment or veto any elements of the performance that did not meet with approval. By this stage the director would also have drawn up a provisional camera plan, plotting the moves of the multiple cameras to be employed in the studio when recording. The 'technical run' would then be attended by camera, lighting and sound crew, again before the move into the studio, to gain some idea of the demands that would be made upon them on the day of recording. This process had evolved in an era when live drama performances were typically given in the evenings, meaning that on the day of transmission at least two technical rehearsals would take place in the studio before broadcast; the first time the actors would have worked with full sets, costumes and props. Even when videotape pre-recording began to replace live transmission in the $1960 \mathrm{~s}$, the same process was maintained, though in the 1970 s evening-only recordings became less common as the 'rehearse/record' model was introduced, allowing separate 
scenes, perhaps utilising the same set, to be recorded throughout the day and edited together in post-production. However, the amount of time allocated for studio work remained the same, with the bulk of preparation still taking place during the Acton rehearsals. When comparing this system with that employed for the theatre, several of the actors who worked at Acton are now critical, Roger Lloyd Pack stating: 'You'd come in and you'd rehearse ... rather like you would a play, really, without the same detail; it was much more perfunctory. Because a lot of television writing is too conventional, and it's not so demanding the same way as theatre plays are. So it wasn't so intense, but you would rehearse it, and the moves and that, and timing, and you'd go over it again. ${ }^{, 42}$ This view of television rehearsal as a 'perfunctory' process, concentrating on repetitious movement and blocking rather than characterisation and text, is supported by Patrick Malahide: 'The rehearsal in the rehearsal rooms wasn't for performance, it was in order to accommodate this huge deal of running these cameras, which were vast things like baby elephants, and they'd be pushed all around the studios on the ends of cables. So that was a very cumbersome process. ${ }^{, 43}$ For Malahide, such rehearsal did little to assist actors in preparing for the final studio performance: 'Looking back at the years I've sat in the Acton Hilton, I find an awful lot of it a dreadful waste of time ... going over and over and over it again; you know, acting to white tape marks on the floor ... The trouble with television, because it was rehearsed in such a way, you got [to the studio] and you couldn't change anything. ${ }^{44}$

There is a clear dichotomy here between the positing of the Acton Hilton as an extension of the stage ensemble, and the major distinction between the type of rehearsals that took place for theatre and TV. Lloyd Pack and Malahide's suggestion that Acton rehearsals were more concerned with blocking than the discussion of text and character typical of stage work would seem to contradict Shaun Sutton's earlier assertion that the process was 'basically no different." ${ }^{45}$ However, such limitations were probably similar to those 
experienced at rehearsal rooms used by independent television companies. The key difference was that, whereas ITV's rooms were usually located in the same block as their studios, ${ }^{46}$ the BBC's facilities were separate and stand-alone; a fact which had a significant impact on the sense of the acting ensemble engendered. Prior to the opening of the Acton building, casts would rehearse in isolation, at locations scattered across London. The sense of company would therefore be restricted to the actors working on a particular production, and might vary depending on the programme format. On a long-running series, the same core group of actors would be meeting on a regular basis, in a manner similar to a theatrical repertory or touring company, whereas on a single play or short serial the sense of 'belonging' to a group might be more focused but shorter-lived; in stage terms, the equivalent of a limited run. The Acton rooms, however, presented something new; a sense of ensemble that extended beyond the production itself. In theatrical terms, the closest equivalent to this extended 'family' of performers might be the old-style variety bill, in which troupes of performers from a variety of acts would rehearse and tour together. In more contemporary terms, a possible parallel exists in the form of London's West End theatre district, in which actors working on Shaftesbury Avenue or Drury Lane have the opportunity to socialise outside their companies in the area's pubs and night-spots. Yet while the Acton site featured its own social focal points via its canteen and the nearby Castle pub, the sense of community also extended into the working space itself. As already seen, it was not uncommon for actors to 'spy' on fellow performers during breaks; not something that would be possible in stage rehearsals, which typically take place in isolated rehearsal rooms or theatres. ${ }^{47}$

This familial atmosphere marked the Acton Hilton out as unique in British and possibly world television, but its history was a comparatively brief one. Although the multicamera studio drama of which Acton rehearsals were a vital component lasted well into the 1980s, by the middle of that decade the Rehearsal Rooms were used far less frequently than 
they had been just a few years before. The BBC's new flagship soap, EastEnders (1985- ) was shot at Elstree Studios in Borehamwood, and never made use of the Hilton's facilities, rehearsal rooms being provided on-site. Long-running children's drama Grange Hill (BBC, 1978-2008) also moved to Elstree Centre in 1985, while several new drama productions, such as Casualty (BBC, 1986- ), developed their own 'standing set' warehouse facilities. While Acton was still operating at $80 \%$ capacity in $1992,{ }^{48}$ the effects of the 1990 Broadcasting Act, which obliged the $\mathrm{BBC}$ to commission $25 \%$ of its output from independent companies, were being felt. As a consequence, much of the drama traditionally produced at Television Centre and rehearsed at Acton was now made by organisations with no similar investment in studio plant. This was followed in 1993 by the instigation of 'Producer Choice', a policy under which producers could use outside suppliers as opposed to internal departments should they prove more cost-effective. 'In-house' BBC drama production between 1992 and 1995 dropped from $74 \%$ to $54 \% .{ }^{49}$ In 1995 the lower three floors at Acton were converted into storage for $\mathrm{BBC}$ wardrobe and wigs. Two years later the remaining floors were converted for office use - with air conditioning finally installed. ${ }^{50}$

There was a brief return to the building's original purpose in 2007, when part of the fourth floor space was cleared to allow 2 Pints of Lager and a Packet of Crisps (BBC, 200111) to rehearse. Following the sale of the wardrobe department, the building stood empty at the end of 2008, when it was offered to the 'Crisis at Christmas' charity as temporary accommodation for the homeless. Still vacant in 2009, the Hilton was purchased by Carphone Warehouse, who promptly sold it on to developer Berkeley First; the latter then opted to demolish the block in favour of constructing student accommodation. ${ }^{51}$

Since the mid-1990s, television drama production has seen a significant shift from multi-camera studio to single camera location work, with a consequent impact on production and rehearsal processes. Little or no prior preparation of the type carried out at the Acton 
Hilton now takes place, contact time with the director usually being limited to a single cast read-through of the script, known as a 'table read', and a brief blocking session on the day of recording. Table reads are conducted in production 'blocks' some time before filming begins, ${ }^{52}$ rather than taking place on the first day of a longer rehearsal process. This means that, rather than focusing on one episode at a time, regular cast members will almost certainly be reading scripts back-to-back for two (or even three) episodes that do not necessarily follow each other in transmission order. While, as seen earlier, a first day rehearsal read-through at Acton would usually have been attended by the core production team, the modern-day equivalent is a much larger affair, director Richard Clark stating: 'The read-through is quite a major event. What you'll find is ... all the producers of the department, the exec producers, you know; everybody turns up to the read-through, and generally full cast, assuming that it's possible. ${ }^{53}$ Whether an actor attends the table read is dependent on a number of variables, not least their character's prominence in the storyline. According to Roger Lloyd Pack, it is not regarded as a necessity by supporting actors: 'Sometimes I elect not to go ... if I'm not featuring that much in it, if it's a guest appearance or whatever; and the fee isn't that brilliant and you think, "No, I won't go.” Or I can’t. It's not considered essential ... and sometimes one is unavailable. They want you for the job but you can't do the read-through; that's not a problem. ${ }^{54}$ Such variable attendance would have been unimaginable at Acton, where a full cast would have been de rigueur on day one to discuss each scene. The sense of company represented by the Hilton now clearly applies only to the regular, core cast, filming sessions having become a much more fragmented experience than was the case in the studio era.

Although the amount of time allocated to a one-hour drama today is little different to what it would have been in the 1970s, comprising approximately a fortnight, the way in which it is utilised has changed drastically. Whereas previously the bulk of production time would have been given over to rehearsal, with studio time comparatively limited, today prior 
rehearsal is virtually non-existent, any preparation typically taking place on day of filming. Although production schedules for an episodic drama provide an average of two weeks' shooting as one half of a production block (often with scenes from different episodes being recorded on the same day), some additional preparation time is allowed prior to the first block of any new series. Howard Burch, an executive producer at Kudos Productions, explains the process: 'You'd start off with the lead director, ${ }^{55}$ and then he would be given that first week of rehearsals ... He probably [uses] three out of the five days for rehearsals, and the rehearsal days [aren't] necessarily that long; you know, they'd probably start at ten, and finish certainly by four. ${ }^{56}$ The fact that so little of the first week is allotted to rehearsal is, according to Burch, due to the remainder being taken up with costume fittings, make-up tests and even last-minute location scouting and script changes. ${ }^{57}$ The few days' rehearsal available to the lead director represents their only opportunity to work closely with actors on particular scenes or discuss characterisation and performance choices; something that would have been a regular part of the rehearsal process at Acton. Once this opening week is concluded, production becomes an on-going routine in which less preparation time is available, as Richard Clark describes: 'When one person is shooting, another one is prepping, another one is editing; so it's a rolling system, basically. And you know, thirteen episodes ... is about as many episodes as we can generally do in this country before you're doing a soap. ${ }^{, 58}$

The period of prior preparation and planning that took place at Acton clearly no longer exists, and the performances which actors now give would seem to be a combination of that provided at their audition (assuming the part was not a straight offer, bypassing the requirement to read), any notes provided after the table read (assuming the actor was in attendance), any preparation they choose to conduct in their own time (either alone, or with fellow cast members), and the direction they receive on the day of filming. The latter can, however, be brief. An extract from Calling the Shots (2007), Graeme Harper's journal of 
directing the modern version of Doctor Who, illustrates the pace at which director and cast now work: 'Eight o'clock in the morning, and everyone's on set, waiting with baited [sic] breath. By nine o'clock we are rehearsed, lit and ready to shoot. ${ }^{59}$ Due to the limited contact time available, Harper tries where possible to talk to his actors before filming begins, ${ }^{60}$ an approach which, though apparently not typical, is shared by fellow director Andrew Gunn:

I always try and either meet with or at least talk on the phone to all the cast ... which I've been told not many directors do ... Even if someone's coming in to do just a few lines for a couple of hours, I will always call them to talk about the story, to talk about the character, to talk about what I expect from them in terms of the level of performance and the style of performance, because there's no point waiting till they turn up on set and then realising that they're thinking in a completely different way. So, it's to make them feel welcome and comfortable and tell them what I want them to do, basically. ${ }^{61}$

In terms of actual rehearsal, directors typically spend just ten to fifteen minutes alone with their actors, reading and then blocking the scene to be filmed. ${ }^{62}$ This is the cast's sole opportunity to raise any issues about which they are unsure, after which the film crew are called in and the scene is performed again. Lighting is then planned, props are set in place, and filming commences; a microcosm of the process that formerly took place at Acton between director and cast.

This diminution of the rehearsal period is, according to Kevin McNally, largely the result of expense: 'You know, nowadays everyone has a trailer of some kind. There were no trailers in the ' 70 s, there were no cars taking you to work in the ${ }^{\prime} 70 \mathrm{~s}$, so there is a great deal more expense ... than there was [then] ... Inevitably something suffers, and plainly booking 
rooms for rehearsals is the thing that goes. ${ }^{63}$ With rehearsals in such decline, the extent to which guest or short-term actors can become part of the 'company' is necessarily limited, as former Brookside (Channel 4, 1982-2003) regular Kenneth Cope points out: 'That's the strange thing. You live with them, in each other's pockets, for three or four, six weeks, whatever, and then you never, ever, ever see them again; you can meet them socially, if you're lucky, but normally you don't. We're bloody gypsies. ${ }^{, 64}$

This sense of rootlessness is in marked contrast to the extended familial atmosphere provided by the Acton Hilton, which seems to have represented a home from home for the acting community. Although the productions worked on may not always have been on-going series, there was the sense that the rehearsal rooms provided a permanent base. Even if the same body of actors working on a particular play was unlikely to be assembled again in the same, specific formation, it would not be long before they were walking the Hilton's corridors and socialising in the canteen once again. Indeed, for the many performers who worked there in the 1970s and 1980s, it almost seems the Acton Hilton was more important for this extended sense of camaraderie than for the work that was carried out there. It should be remembered, of course, that this fortunate (for those who worked there) state of affairs was the serendipitous result of hard-nosed executive decisions, rather than a calculated attempt to engender an extended performing community. Nevertheless, from a simple investment in the updating and consolidation of an existing rehearsal system, the Acton Rehearsal Rooms became, in a sense, the fulcrum of the BBC's entertainment world. This was an environment which is, according to Kevin McNally, now lost for ever:

The interesting thing about it - and I'm sorry to get sentimental, but I'm sure everyone will have told you - what all actors of my generation miss is that sense of the community, the acting community. We would all meet at the Acton rehearsal rooms; everything that was working there was rehearsing in 
that building, you know, so there was a wonderful sense of meeting people socially ... And one misses that being gone; it's absolutely obvious that, in the modern climate, that sort of concentration of materials, like having a rehearsal room, and all of those shows going, can't happen any more. But on the other hand it is now a ludicrous indicator of how strange the business is, that that building is the only copyright offices with sprung dance floors. I mean - what a waste of that building. ${ }^{65}$

When that interview was recorded, in November 2010, the process of demolishing the Acton rooms was in fact already complete. Its replacement, 'The Costume Store', now houses 730 UAL students.

While perhaps not as iconic as Television Centre, the Acton Hilton symbolises not only a mode of television production that is, with the exception of sitcom and possibly talent shows, now virtually extinct, but also a particular period in British television acting, where a new type of performing community began to emerge. This was distinct from both the tightknit repertory group and the cinema industry in terms of its centralised location and multiplicity of formats, its component members not being limited to one production, series or genre of programme-making alone. Whether such an extended community could flourish in the current era of media cities and drama centres - the 'dream factories' of tomorrow, perhaps - remains to be seen; from the comments of those featured here, it seems unlikely that these new endeavours will recapture quite the same collaborative spirit as that which existed at the Hilton. 


\section{Notes}

${ }^{1}$ Tim Masters, BBC TV Centre: goodbye to the 'dream factory', BBC News, Entertainment and Arts, 22 March 2013, http://www.bbc.co.uk/news/entertainment-arts-21828033.

${ }^{2}$ http://tech-ops.co.uk/acton/.

${ }^{3}$ Mike Jones, 'In the Beginning', Acton Hilton, 2010, http://tech-ops.co.uk/acton/his.html.

${ }^{4}$ Ibid.

${ }^{5}$ BBC Written Archives Centre R37/111/1 - List of BBC Properties, 21 September 1959.

${ }^{6}$ BBC WAC T17/156 - Memo from A.M. Andrews, Administration Officer, 25 January 1954.

${ }^{7}$ BBC WAC T17/156 - 'Television Centre: Review of Accommodation - Rehearsal Rooms', 25 January 1954.

${ }^{8}$ BBC WAC T17/156 - Memo, 25 January 1954.

${ }^{9} \mathrm{BBC}$ WAC T17/156 - Memo, 18 June 1954.

${ }^{10}$ BBC WAC T17/156 - 'Permanent Rehearsals Block for Television: Note by Consulting Civil Engineer', 28 October 1954.

${ }^{11}$ Ibid.

${ }^{12}$ Ibid.

${ }^{13}$ BBC WAC T16/16/2 - Letter from G.M. Turnell, Head of Programme Contracts, 24 June 1964.

${ }^{14}$ Alvin Rakoff, interviewed by the author, 27 April 2011.

${ }^{15}$ BBC WAC R37/112/1 - Memo from P.A. Florence, Head of Central Services Group, 4 January 1963.

${ }^{16}$ BBC WAC R37/91/1 - Memo from D.A. Heycock, Assistant Head of Central Services, 11 September 1965.

${ }^{17}$ BBC WAC T16/16/2 - Memo from D. Hemmings, Senior Assitant (General) Television Administration, 8 October 1962.

${ }^{18}$ BBC WAC R36/82/1 - Memo from B. Lamb, Assistant to Central Services Planning Officer, 27 May 1960.

${ }^{19}$ R36/82/1 - Letter from Dame Edith Evans, 15 April 1961.

${ }^{20}$ BBC WAC T16/16/2 - Letter from Hugh Jenkins to the Architect, London County Council, 1 May 1964.

${ }^{21}$ BBC WAC R36/82/1 - P.A. Florence, B.E. Adams, 'Rehearsal Facilities', 6 June 1963.

${ }^{22}$ Ibid.

${ }^{23}$ Jones, 'In the Beginning', 2010

${ }^{24}$ BBC WAC R35/1,662/1 - Memo from Head of Central Services Group, 7 April 1967.

${ }^{25}$ BBC WAC R35/1,663/1, Victoria Road, North Acton, TV Rehearsal Rooms: lease.

${ }^{26}$ BBC WAC R35/1,662/1 - Letter from solicitor M.S. Day, 21 September 1970.

${ }^{27}$ BBC WAC R37/91/1 - Memo from A.M. Andrews, Head of Central Services Group, 3 September 1968.

${ }^{28}$ BBC WAC R35/1,662/1 - Letter from N.E.L. Thomas, Assistant to Central Services Planning Officer, 3 April 1970.

${ }^{29}$ Jones, 'In the Beginning', 2010

${ }^{30}$ Mike Jones, 'TRR Specification', Acton Hilton, 2010, http://tech-ops.co.uk/acton/trrspecs.html.

31 'Bumping into the Stars over North Acton', Acton Gazette, 21 May 1970.

${ }^{32}$ Elisabeth Sladen, The Autobiography (London, 2011), 78-9.

${ }^{33}$ Stephen Fry, The Fry Chronicles: an autobiography (London, 2010), 217-218.

${ }^{34}$ Matthew Waterhouse, Blue Box Boy (Hants, 2010), 160.

${ }^{35}$ Robin Ellis, Making Poldark (Cornwall, 1978), 29.

${ }^{36}$ Roger Lloyd Pack, interviewed by the author, 20 January 2011.

${ }^{37}$ Kevin McNally, interviewed by the author, 9 November 2010.

${ }^{38}$ Waterhouse 2010, 160.

${ }^{39}$ McNally 2010.

${ }^{40}$ Michael Sanderson, From Irving to Olivier: a social history of the acting profession in England 1880-1983

(London, 1984), 279.

${ }^{41}$ Shaun Sutton, The Largest Theatre in the World (London, 1982), 112.

${ }^{42}$ Lloyd Pack 2011; previously cited in Richard Hewett, 'Acting in the New World: Studio and Location Realism in Survivors', Journal of British Cinema and Television 10.2 (2013), 326.

${ }^{43}$ Patrick Malahide, interviewed by the author, 13 June 2011; previously cited in Hewett 2013, 326.

${ }^{44}$ Ibid; previously cited in Hewett 2013, 327.

${ }^{45}$ Sutton 1982, 112.

${ }^{46}$ This varied depending on the company. A BBC investigation found that 'some of the larger companies, such as Associated-Rediffusion and Granada, do have rehearsal rooms in their own buildings, but some of the smaller companies, such as Anglia, hire halls in the same way we do.' BBC WAC T16/16/2 - Memo from Legal

Advisor, 13 February 1963. 


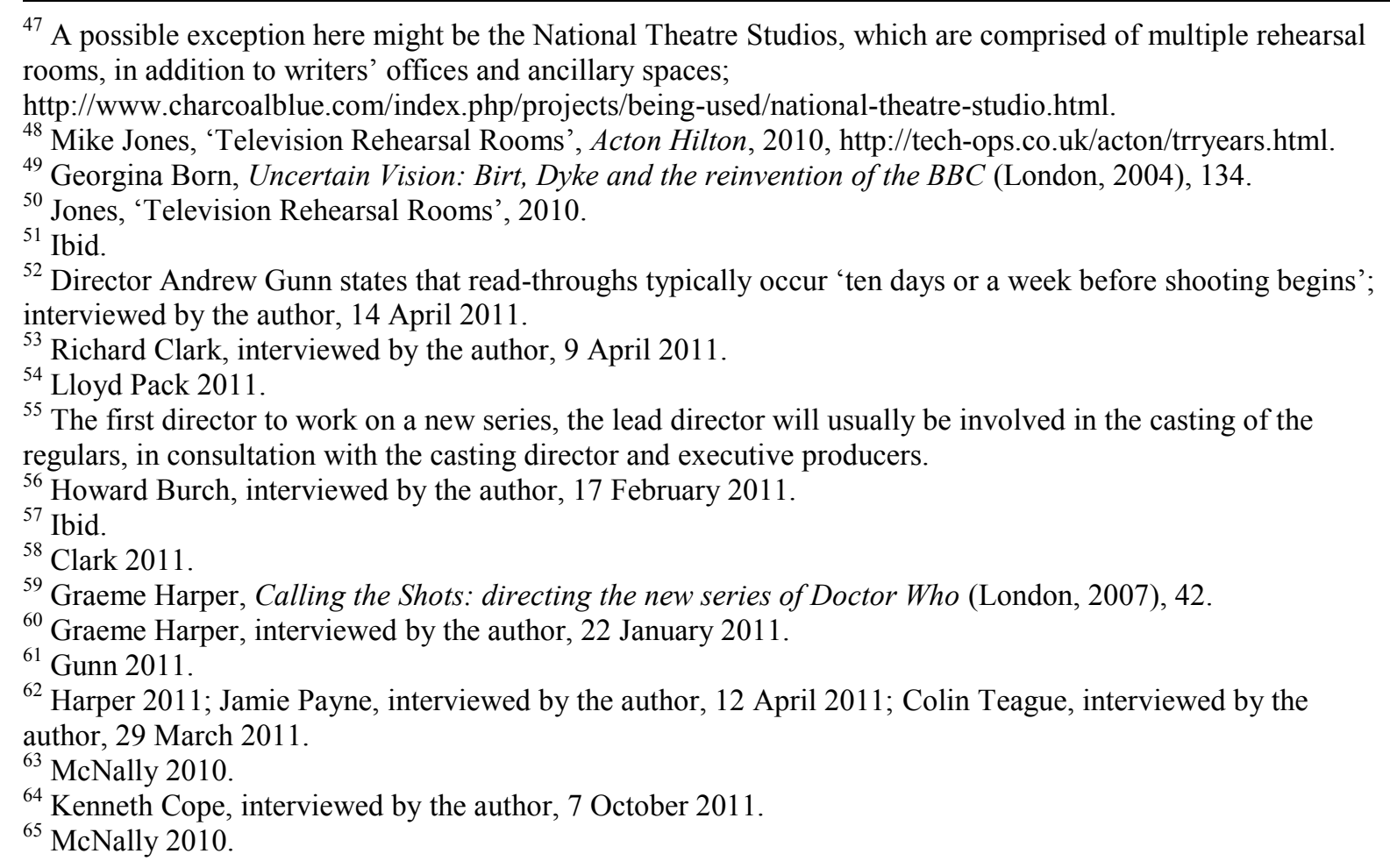

